\title{
E-LEARNING ABC
}

Ma már nagyon sokan találkoznak az e-learning kifejezéssel, azonban a mögé képzelt tartalom egyénenként eltérő lehet: az e-learning gyors fejlődése és térnyerése következtében rengeteg új fogalom alakult ki és terjedt el, melyek definíciója korántsem egységes, megnehezítve az eligazodást még a szakemberek számára is. Ennek feloldása fontos feladat: a cikk elsósorban e fogalmakat igyekszik tisztázni a nemzetközi szakirodalom széles körú áttekintésével, az egyes szerző́k különböző megközelítéseit alapul véve és összevetve. Az alapvető fogalmak definiálásán túl a szerző meghatározza az e-learning összetevőit (rendszer, résztvevő́k és tartalom) és azok jellemzőit. Végezetül példákon keresztül mutatja be az e-learning lehetséges alkalmazási területeit és az ezekhez tartozó specifikus elemeket, ezzel kontextusba helyezve a laikusok számára is az e-learningben rejló lehetőségeket, és a gyakorlatban már alkalmazott megoldásokat. A cikk végén rövid kitekintést tesz azokra a kihívásokra, amelyek az e-learning megjelenésével bukkannak fel az oktatás területén.

\section{Kulcsszavak: e-learning, online oktatás, blended learning, oktatási formák, e-learning rendszer, e-tananyag}

A számítógépes technológiák és az internet intenzív fejlődésével és terjedésével az e-learning megoldások is egyre nagyobb teret nyernek az oktatás világában legyen szó közoktatásról, vagy vállalati környezetről. Bár az e-learning térnyerése kétségtelen, mégis nehéz meghatározni, pontosan mit is értünk e viszonylag új fogalom alatt. Köszönhetően a gyors ütemben zajló technológiai fejlödésnek, maga a definíció is rugalmasan változik, az esetleges konszenzusokat is könnyedén félre lehet értelmezni. Ahogy Moore et al. (2011) is rávilágít, éppen ebből a definíciós problémából kiindulva megnehezül a kutatók dolga, hiszen nehéz úgy elemzéseket és kimutatásokat végezni, ha a rendelkezésre álló különféle adatbázisok - vagy éppen a fókuszba állított célközönség - másként értelmezik az e-learninget és a kapcsolódó fogalmakat. Míg sok-sok évvel ezelőtt az átlagembernek az e-learningről alkotott képe kimerült egy elektronikus dokumentumból való tanulásban, mára már különféle oktatóvideók, vagy akár virtuális, kiterjesztett valóságok jutnak az eszünkbe.

Napjainkban az e-learning megoldások egyik zászlóshajójának sokan a felsőoktatási intézményeket tekintik, hiszen az amerikai egyetemekről indult MOOC (Massive Open Online Course) képzések komoly beruházásokon keresztül fejlesztik ezt a képességet és technológiát. A téma relevanciáját a napjainkban gyakran használatos „élethosszig tartó tanulás” (,lifelong learning”) adja, amelynek Field (2000) egy teljes könyvet szentelt, ugyanakkor érdemes megjegyezni, hogy a távoktatásnak az élethosszig tartó tanulásra gyakorolt hatását, és az ebben rejlő lehetőségeit már Clark 1989-es munkájában is megtalálhatjuk. Sir Ken Robinson (2006) egyik legismertebb TED előadásában már tíz évvel ezelőtt arról beszélt, hogyan csökken az értéke a jelenlegi oktatási rendszerben megszerezhető minősítéseknek (érettségik, alap- és mesterszintủ diplomák, $\mathrm{PhD}$-fokozatok stb.). Ebből fakadóan meg kell reformálni a jelenlegi rendszert, amelyben kulcsszerepe lehet az e-learningnek. Ken Robinson (2010) későbbi előadásában a fenti gondolatmenetet folytatva pedig már arról beszél, hogy az oktatásnak a kreativitásra kell építenie, nem pedig az oktató gondolatainak egy-az-egyben való átültetéséről kell szólnia. Ehhez szintén jó eszköztárat biztosít az e-learning.

A fentiekből kiindulva cikkemben azt a feladatot tüztem ki célul, hogy összegezzem a leggyakoribb megközelítéseket, amelyek e témát járják körül, és kutatótársaim munkáját alapul véve tisztázzam az e-learning és a kapcsolódó fogalmak - mint például távoktatás (distance learning), mobil oktatás (mobile learning), kevert oktatás (blended learning) - jelentését, behatároljam alkalmazási területeit és a kapcsolódó hajtóerőket, végül pedig kitérjek a témában rejlő kihívásokra és a további kutatási lehetőségekre. A nyelvi akadályokat áthidalva cikkemben a különböző szerzők által használt kifejezések eredeti, angol nyelvü változatait is feltüntetem.

Cikkem a fogalmi tisztázásokból fakadóan egyrészről hasznos lehet a témában jártasok számára, hogy támpontot adjon további kutatásokhoz, kvantitatív elemzésekhez. Érdekes lehet ugyanakkor azon laikusok számára is, akik az e-learninggel még csak futólag találkoztak, esetleg olyan projektek és feladatok előtt állnak, amelyekhez elengedhetetlen tisztán átlátni az e-learninget körülölelő fo- 
galmi hálót, a háló elemeinek kapcsolódási pontjait. Nem célom azonban az e-learning mások által megfogalmazott előnyeit és hátrányait érvekkel alátámasztani vagy éppen bizonyítani, ezek tartalmáról az Olvasót meggyőzni.

\section{Terminológiai megközelítések}

Bár az e-learningnek egyre szélesebb kutatói és irodalmi háttere van, egyezményes definícióról még nem beszélhetünk. Ahogyan arra Guri-Rosenblit et al. (2011), illetve Sangrá et al. (2012) is rávilágít: az e-learning definíciók négy csoportba különíthetők el, melyek alapját elsősorban a definíció megközelítései adják. Ilyen formán beszélhetünk:

- technológiai megközelítésről (technology driven), - az elérhetőség útjából kiinduló megközelítésről (delivery function),

- a kommunikációt és interakciót középpontba helyező megközelítésről (communication and interaction), illetve

- a fentiektől kicsit tágabb értelmezésben véve egy új paradigmáról (educational paradigm).

\section{A technológia}

Ahogy Sangrá et al. (2012) is idézi, ,e-learningnek nevezzük azt az online képzési formát, amikor egy képzést modern, vezeték nélküli vagy vezetékes kapcsolaton keresztül teszünk elérhetővé, hogy hozzáférjünk akadémiai tananyagokhoz számítógépről, telefonról, vagy más hordozható eszközröl" (Governors State University, 2008). Ez a megközelítés tehát elsősorban a technológiát helyezi fókuszba, és a tartalomtól vagy akár célközönségtől függetlenül azt mondja ki, hogy az e-learning tartalom a számítógépen keresztül, online érhető el. Véleményem szerint ez a fajta definiálás meglehetősen tág, ami két dolgot eredményez:

1. feltehetőleg sokáig érvényes marad, hiszen az e-learning online mivolta elég stabil alapot képez, illetve magát az eszközkészletet is kellöen szélesen határozza meg a „handheld device” kifejezéssel,

2. ugyanakkor a laza definíció nem kellően pontos, így célzott kutatásokban nehéz alkalmazni.

Fentiekből fakadóan célszerünek találnám az idézett definíción túl egy - vagy akár több - szükebb meghatározás felállítását is. Ha abból indulunk ki, hogy a szűkebb definíciónak elengedhetetlen eleme lesz a technológiai tényező, akkor ez a szükebb meghatározás bár gyakrabban felülvizsgálatra szorulhat, azonban az aktuális, időben közel eső kutatásokban nagyobb összehasonlíthatóságot eredményezhet.

\section{Az elérés}

Abbas et al. (2005, p. 11.) a következőképpen fogalmazott: „Az e-learning lazán definiálható úgy, mint alkalmazások és folyamatok széles tárháza, amelyek elektronikus médiát és eszközöket alkalmaznak szakmai tudás átadására" ${ }^{2}$. Az elérés útját középpontba helyező megközelítés láthatólag szintén figyelembe veszi az előző pontban már feszegetett technológiai szükségletet, azonban a technológiát csak egy eszköznek tekinti, a hangsúlyt pedig magára a tudásátadásra helyezi.

\section{Kommunikáció és interakció}

A tanuló és oktató közötti, vagy akár a tanuló-tanuló kommunikáció a tudásbővítés és tudásszerzés egyik elsődleges forrása, legyen szó előadásokról, kerekasztal-beszélgetésekről, vagy akár az adott témában kialakult vitákról. Herrington et al. (2000) az oktatásnak éppen erre a kommunikáción alapuló mivoltára helyezi a hangsúlyt, amikor tanulmányában arra hívja fel a figyelmet, hogy az e-learning éppen ezt a tanulók közötti interakciót képes rendkívül hatékonyan támogatni a különbözö, technológiailag megfelelően támogatott kommunikációs formákon keresztül, külön kiemelve a csoportos tanulást és a kollaboratív tanulási környezetet. Érdemes megfigyelni, hogy a technológia itt is szerves részét képezi a definíciónak, hiszen a kommunikációs megoldásokat a technológia adta lehetőségekre vezeti vissza a szerző.

\section{Az oktatási paradigma}

Az elóző háromhoz képest ez már egy kicsit összefoglaló, átfogóbb megközelítést mutat, amely az e-learninget egy teljesen új oktatási paradigmaként fogja föl. Itt érdemes megemlíteni Khan (2005, p. 140.) definícióját, aki például az e-learninget egy innovatív megközelítésnek nevezi, amely egy jól megtervezett, tanulócentrikus, interaktív tanulási környezetet garantál bárkinek, bárhol, bármikor³. Henri (2001, p. 249.) megfogalmazásában érdemes megfigyelni, ahogy az e-learninget a konkrét technológiától, a tartalomtól és az infrastruktúrától függetlenné teszi, mégis esszenciálisnak ítéli meg. Ugyanakkor nála is megjelenik a „delivery" funkció, amely a 2. pontban taglalt megközelítés alapját képezte: „(az e-learning) az internet megfelelő alkalmazása, amely támogatja a tanulás, a képességek és a tudás átadását egy olyan holisztikus megközelítésben, amelyet nem korlátoz sem egy adott téma, sem a technológia, sem az infrastruktúra"4.

\section{Az egyes megközelítések kapcsolata}

A fenti megközelítéseknél kiemelt egy-egy szerző, vagy publikációban található definíció csak szemléletes példája az adott iskolának, fontos azonban megjegyezni, hogy a fenti csoportosításba számos további, a fentiekben idézettektől csak árnyalatnyi különbségekben eltérő definíció 
Az e-learning fogalmi megközelítések csoportosítása a különböző tanulmányok alapján (Sangrá et al., 2012 alapján)

\begin{tabular}{|l|l|}
\hline Megközelítés & Kapcsolódó tanulmányok \\
\hline Technológia & $\begin{array}{l}\text { Guri-Rosenblit, S. (2005): 'Distance education' and 'e-learning': Not the same thing } \\
\text { Governors State University, Center for Online Learning and Teaching (2008): E-learning } \\
\text { glossary (www.govst.edu) } \\
\text { Marquès, P. (2006): Definición del e-learning } \\
\text { E-learning Portal (2009): E-learning glossary (http://www.e-learningguru.com) }\end{array}$ \\
\hline Koohang, A. - Harman, K. (2005): Open source: A metaphor for e-learning \\
Lee, T. - Lee, J. (2006): Quality assurance of web based e-learning for statistical education \\
Li, F. W. - Lau, R. W. - Dharmendran, P. (2009): A three-tier profiling framework for \\
adaptive e-learning \\
Liao, H. - Lu, H. (2008): Richness versus parsimony antecedents of technology adoption \\
model for E-learning websites
\end{tabular}

sorolható be. E szerzők széleskörüségét foglalja össze az 1. táblázat (Sangrá et al. 2012-es cikke alapján).

Felülnézetből megvizsgálva a Sangrá et al. (2012) által meghatározott megközelítéseket, azok között öszszefüggéseket vehetünk észre, amelyek a legszemléletesebb módon egy folyamatba illesztve adhatnak teljes képet. Magának az e-learningnek szüksége van bizonyos erőforrásokra, amelyek jelentik egyrészt a technológiát, másrészt magát a szakmai anyagot, amelyet az oktatók testesítenek meg. Ahhoz, hogy a tudás eljusson a tanulóhoz, szükséges valamilyen csatorna, amely a kommunikáció egy bizonyos - az elöbbiekben említett technológia által támogatott - formája lehet, s jellemzően az

\section{Az e-learning fogalmi megközelítéseinek folyamatszemléletú ábrázolása}

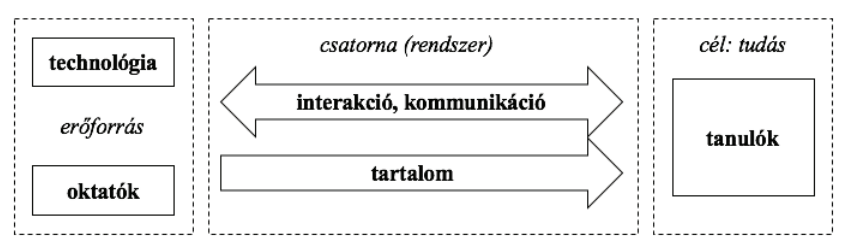

Forrás: saját szerkesztés interneten keresztül valósul meg. Végeredményképpen pedig a fogadó oldalon maga a tanuló áll, akiben az elözőeknek köszönhetően kialakul az új tudás. (1. ábra)

\section{Kapcsolódó oktatási formák}

A fenti definíciók és megközelítések jó alapot képeznek az e-learning megértéséhez, azonban kevesek ahhoz, hogy közelebb hozzák a fogalmat a laikusok számára. Ehhez célszerü megvizsgálni azokat az egyéb oktatási formákat, amelyek valamilyen módon szerves részét képezik az e-learning világának, kapcsolódnak ahhoz. A továbbiakban kitérek ezekre a területekre, így megvizsgálom a távoktatás (distance education) fogalmát és legfontosabb jellemzőit, a kevert képzéseket (blended learning), illetve a mobil tanulást (mobile learning). $\mathrm{Ez}$ a három kulcselem gyakran átfedésben és hasonló kontextusban, vagy az e-learning szinonimájaként hangzik el mind hétköznapi, mind tudományos közegekben, fontos azonban megjegyezni, hogy egyik sem egyenértékủ azzal, még ha szorosan kötődnek is hozzá.

\section{A távoktatás (distance education)}

A távoktatás és az e-learning kapcsolata sokak számára kérdéses. Moore (2011) cikkében kimondottan arra 
fókuszál, hogy a szakirodalom hogyan definiálja az egyes tanulási környezeteket, továbbá empirikus kutatást is végez, amelynek eredményeképpen rávilágít a téma körül fellelhetö fogalmi zavarra. Cikkében a távoktatás definíciójának keresése közben elsősorban a földrajzi távolságra alapoz, ugyanakkor felhívja rá a figyelmet, hogy a távolság időben is értelmezendő (aszinkron tanulás). Fontos még kiemelni a távoktatás (distance education) és távtanulás (distance learning) közötti terminológiai különbséget, melyet sokan szinonimaként használnak. King et al. (2001) azonban rávilágít, hogy a távtanulás (distance learning) egy tágabb fogalom, amely bármilyen tudás megszerzését (megtanulását) jelenti, amely valamilyen közvetítőn keresztül zajlik; ennek a fogalomnak viszont csak egy részhalmazát képezi a szervezett keretek között zajló távoktatás, amely már feltételezi egy oktató közvetlen vagy közvetett szerepét.

\section{A mobil tanulás (mobile learning)}

A mobil tanulás azon fogalmak közé tartozik, amely bár definíció szerint szerencsére könnyebben megfogható, azonban a laikusok gyakran csak szűk látókörüen értelmezik a kifejezést. A mobiltechnológiáknak köszönhetően (és itt az angol terminológiából fakadóan beleérthetünk nem csak mobiltelefont, hanem tabletet, laptopot, vagy gyakorlatilag bármilyen egyéb hordozható, „mobil” eszközt) a tanulás folyamata rengeteg új lehetőséggel és támogató funkcióval egészíthető ki. Fontos kiemelni azonban, hogy ezek az eszközök nem csak és kizárólag a távtanulást segítik, hanem a hagyományos, jelenléti oktatások során is hasznos elemei lehetnek a tudásbővítésnek (Martin et al., 2013). Gondoljunk például egy csoportos esettanulmány-megoldásra, ahol a tanulók az interneten fellelhető információkat hívják segítségül, vagy egy osztályteremben megvalósított anonim szavazásra egymás munkájának értékeléséröl, amelyet mobileszközök segítségével (például okostelefonjukkal) valósítanak meg a tanulók. Kicsit jobban elrugaszkodva a hétköznapi példáktól, megemlíthetünk olyan lehetőségeket is, amelyekkel a tanulók a valóságban nehezen megvalósítható szimulációkat hajthatnak végre a tanteremben (fizika, kémia) a megfelelő célszoftverek és eszközök segítségével. Ezeken felül pedig ott vannak azok a triviális lehetöségek, amelyek már a távoktatást teszik lehetővé, mint például az online kurzusok, amelyeket időtől és helytől függetlenül végezhetnek el a tanulók.

\section{A kevert képzés (blended learning)}

Egy másik szemszögből megközelítve az e-learninget beszélhetünk az úgynevezett kevert (vagy vegyes) képzésekről (blended learning, vagy néhol megjelenik mint hybrid learning), amely nem pusztán jelenléti, vagy táv- oktatásként valósul meg, hanem a kettő valamilyen arányú egyvelegeként. A kevert képzések definiálásához Drysdale el al. (2013, p. 90.) munkája nyújt kiváló alapokat: a szerzők 205 doktori disszertációt vizsgáltak és elemeztek, amelyek valamilyen módon kapcsolódtak a kevert képzésekhez. A fogalom a lehető legegyszerübb formájában a következőképpen írható le: ,,az online és a szemtől-szemben történő oktatás gondos integrálása"`. Mint az a tanulmányból is kiderül, a kevert képzés igen gyakori mind a felsőoktatásban, mind a vállalati környezetben, hiszen mind az online, mind a jelenléti képzésnek megvannak az előnyei, melyek megfelelő kombinációja egy rendkívül hatékony oktatási formát és tudásátadást eredményezhet.

\section{Az e-learning alkotórészei}

A fenti három kulcsfogalmon túl a továbbiakban kitekintést teszek azokra a kisebb egységekre, amelyek már az e-learning megoldások szerves elemeit képezik. Az e-learning összetevői alapvetően három kategóriába sorolhatók, melyeket a következőképpen definiálhatunk:

1. Szereplők: minden olyan (emberi) résztvevő a folyamatban, aki az online tanuláshoz valamilyen formában hozzájárul,

2. Tartalom: azok a szakmai tartalmak, tananyagok, amelyeket a tanulók a tanulási folyamat során elsajátítanak,

3. Rendszer: valamilyen - általában online elérhető - informatikai rendszer, amely lehetővé teszi a résztvevők azonosítását, a tartalom tárolását és „fogyasztását”, illetve a tanulási folyamat részletes nyomon követését.

$\mathrm{Az}$ e-learning fenti kulcselemei olyannyira esszenciálisak, hogy gyakorlatilag egyik sem hagyható ki az e-learning „képletéből”. Értelmetlenné válik ugyanis az e-learning, ha nincs tanuló, aki ilyen formán sajátítana

\section{Az e-learning alkotórészeinek egy lehetséges kapcsolatrendszere}

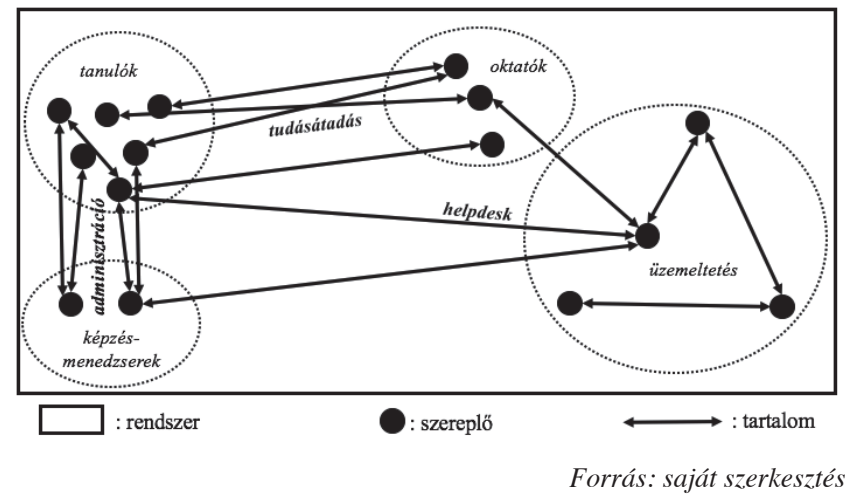


el tudást, ha nincs tartalom, amit elsajátíthat a tanuló, ha nincs rendszer, amelyen keresztül a tanulók hozzáférhetnek a tudáshoz. A három alkotórész közötti kapcsolatot a mindennapi életből hozott példával élve a legkönnyebb megérteni: képzeljük el a rendszert egy HiFi-ként, a tartalmat egy CD-ként, a szereplőt pedig akár mint a CD-n éneklő előadót, akár mint a hangfal előtt ülő hallgatót. A zenehallgatáshoz (a mi példánkban a tanuláshoz) mindhárom összetevőre szükség van. (2. ábra)

\section{A szereplók}

Az e-learning folyamatának kulcsszereplői tehát azok az emberek, akik a végső célhoz, azaz a tudásátadáshoz hozzájárulnak. A legtriviálisabb értelemszerüen ezek közül a tanuló, illetve az oktató, ezt a listát azonban még számos, további egyénnel lehet bővíteni. Fontos kiemelni, hogy egy képzés kontextusában természetesen egy-egy szereplöből több is előfordulhat - és jellemzően elö is fordul.

A legfontosabb szereplők és jellemzőik:

- a tanuló: azok a személyek, akik önként vagy valamilyen külső kötelezettségnek eleget téve részt vesznek az e-learning képzésen, a köznyelvben e-tanulóként (e-student) is hívják őket.

- az oktató: az e-learning képzésben elsajátítandó tananyagot átadó személy(ek). Az oktató az, aki teljes mértékben tisztában van a képzés szakmai oldalával, azonban nem feltétlenül képes arra, hogy azt e-learning megoldással átadhatóvá tegye. Az angol terminológiában általában ,instructor"-ként hivatkoznak rá, mintsem a klasszikus „teacher” szóval.

- tutor: ideális esetben az e-learning egyik velejárója a tutorálás is, mely az e-tanulók menedzselését és „,coach-olását jelenti. A tutorok feladatai közé tartozik a tanulók előzetes tudásának (bemeneti kompetenciák), elvárásainak felmérése, fejlődésük nyomon követése, a motiváció fenntartása, sőt, akár a tanulást követően az utólagos mentorálás is (Allen, 2013). Az oktatók nem szükségszerüen, de lehetnek egyben a tutorok is.

- a tananyagfejlesztö: olyan pedagógiai-módszertani és informatikai ismeretekkel is rendelkező szakember, aki az online tananyagok elóállításában közremüködik. Tananyagfejlesztö lehet maga az oktató is, szerepe azonban általában azért különül el attól, mert a hagyományos képzésekhez szokott oktatók nehezebben képesek az új oktatási megoldásokra átültetni a tananyagot.

- a képzésszervező: az a személy, aki a képzések karbantartásáért felel. Feladatai közé tartozik a képzések meghirdetése, megszervezése, lebonyolítása, a kapcsolódó adminisztráció elvégzése.
- a rendszergazda: az e-learning rendszer fenntartásáért és üzemeltetéséért felelős személy. Mivel az e-learning nagyban támaszkodik az informatikára, ezért a kapcsolódó résztvevők tovább bonthatók, most az egyszerüség kedvéért ide értjük például a rendszer használatának elsajátítását és az esetlegesen felmerülő problémamegoldást segítö ügyfélszolgálatot is.

Bár néhol külön kiemeltem, összességében is fontos megjegyezni, hogy a tanulót leszámítva a többi szerepkör között gyakorlatilag szabad átjárás és átfedés lehetséges, függően a szervezeti kultúrától és az adott személy kompetenciáitól. Ilyen formán elképzelhető például, hogy egy e-learning képzés esetén az oktató egyben a tananyagfejlesztő, a tutor, a képzésszervező és a rendszergazda is. Bár ezek a feladatok önmagukban is meglehetősen nagy volumenüek lehetnek, de nem elképzelhetetlen egy ilyen szélsőséges kombináció sem.

\section{A tartalom}

Az e-learning képzések tartalmi elemeinek kidolgozottsága és formája kulcsfontosságú az e-learning oktatás hatékonysága szempontjából. Bár az e-learning tartalom kapcsán elsősorban valamilyen konkrét online tananyagra asszociálunk, fontos kiemelni, hogy ide tartoznak a kiegészítő tanulási elemek is, mint például egy fogalomtár, szószedet, hivatkozásgyüjtemény, esettanulmányok és gyakorló feladatok stb., amelyeket terjedelmi okokból most csak felsorolás szintjén említek.

Ahhoz, hogy az e-learning tananyagok könnyedén tudjanak kommunikálni az őket tároló és lejátszó e-learning rendszerekkel (bővebben lásd a következő alfejezetben), általában valamilyen nemzetközileg elterjedt, az e-learning rendszerek által támogatott szabvány szerint érdemes őket elkészíteni. Az e-learning tananyagok kifejlesztése történhet valamilyen egyedi programozási megoldással, vagy erre alkalmas tananyagfejlesztő szoftverek (pl. Articulate Storyline, Adobe Captivate, iSpring Suite stb.) segítségével. Utóbbiak szinte kivétel nélkül rendelkeznek olyan publikálási (exportálási) funkcióval, amelyek a legismertebb, SCORM (Sharable Content Object Reference Model) e-learning szabvány szerint állítják elő a tananyagot. A SCORM egy olyan szabvány, amely lehetővé teszi, hogy az e-learning rendszerbe töltött tananyagok kommunikáljanak a rendszerrel, átadják a tanulók elörehaladási adatait, teszteredményeit stb. (Parmar, 2012). Bár a 2000-ben megjelent SCORM 1.0 szabványt az elmúlt évtizedben folyamatosan fejlesztették, hátránya lehet, hogy 2009 márciusában jelent meg az utolsó, SCORM 2004 4th Edition névre keresztelt változata - helyét a következő években a TinCan API veheti át fokozatosan. 
A feltörekvőben lévő TinCan API (vagy más néven Experience API vagy xAPI) Poltrack et al. (2012) alapján a SCORM következő generációját jelenti, melynek első teljes körü (1.0-ás) változata 2013-ban jelent meg. Ez a szabvány már sokkal tágabb kereteket ad a rendszer és a tananyag közötti kommunikációra, azonban egyelőre még kevésbé elterjedt. Mind a rendszerek, mind a tananyagfejlesztő szoftverek most kezdik átvenni és integrálni alkalmazásaikba az új szabványt, egyelőre inkább az egyedi fejlesztésủ e-learning infrastruktúrákban jellemző az alkalmazása.

A szabványokon túl az e-learning tananyagok egyik jellemzője az a technológia, amellyel a tudásátadást megvalósítják. Mittal et al. (2006) az e-learning tananyagok csoportosításakor a következő négy típust határozza meg:
A 2. táblázat összefoglalja, hogy az egyes tananyagtípusokat többek között milyen tananyagfejlesztő célszoftver segítségével lehet előállítani.

\section{A rendszer}

Az e-learning infrastruktúra esszenciális, harmadik összetevője maga az e-learning rendszer. A jelenleg elérhető e-learning rendszerek között találhatunk ingyenes, szabadon terjeszthető, nyílt forráskódú rendszereket (pl. Moodle, Ilias stb.), melyek fejlesztése folyamatosan zajlik, és kihasználják a nyílt forráskód adta lehetőségeket, meglehetősen nagy fejlesztői bázist kiépítve (Krishnamurthy et al., 2013). Ugyanakkor a nagyobb vállalati rendszerek készítői is kifejlesztették saját e-learning rendszereiket (pl. SAP LSO, Oracle iLearning stb.), amelyeket természetesen integráltak a

2. táblázat

Az egyes tananyagtípusok elóállítására alkalmas célszoftverek (saját szerkesztés)

\begin{tabular}{|l|l|}
\hline Tananyagtípus & Elóállítására alkalmas célszoftver (tananyagfejlesztó program) \\
\hline $\begin{array}{l}\text { Egyszerú szöveges tan- } \\
\text { anyag }\end{array}$ & $\begin{array}{l}\text { Microsoft Word, HTML, CSS, JavaScript programozás, Adobe InDesign, Mood- } \\
\text { le „Lecke” modul }\end{array}$ \\
\hline $\begin{array}{l}\text { Interaktív, multimédiás } \\
\text { tananyag }\end{array}$ & iSpring Suite, Articulate Storyline, Lectora \\
\hline Videóalapú tananyag & $\begin{array}{l}\text { Microsoft PowerPoint vagy prezi.com a háttérkészítéshez, Adobe Premiere a videó- } \\
\text { vágáshoz és HTML, CSS, JavaScript programozás a videólejátszó elkészítéséhez }\end{array}$ \\
\hline Szimulációs tananyag & Adobe Captivate, Camtasia Studio \\
\hline
\end{tabular}

1. egyszerü szöveges tananyag: olyan alacsony interaktivitású és multimédiás tartalommal ellátott tananyagok, amelyek alapvetően passzív módon, olvasással sajátítandók el,

2. interaktív, multimédiás tananyag: e tananyagok egyik fó jellemzője, hogy a tanulót aktivitásra ösztönzik a különböző interakciókon keresztül (pl. kattintásra megjelenő tartalmi elemek, játékos feladatok), ezek a tananyagok általában multimédiás elemekben (képek, animációk, narráció, videók) is gazdagok,

3. videóalapú tananyag: a hagyományos jelenléti oktatási formát idéző tananyagok, amelyekben az oktató általában mint élőszereplő megjelenik a tananyagban, ennél a tananyagtípusnál gondolhatunk akár egy kamerával rögzített, online elérhetővé tett tantermi oktatásra, vagy speciális, pl. greenbox technikával felvett, egyedileg megvágott és összeállított tananyagra,

4. szimulációs tananyag: leginkább számítógépes szoftverek oktatására használt e-learning tananyagtípus, melynek jellemzője, hogy az oktatandó alkalmazást erre alkalmas célszoftverek leképezik, ezáltal szimulálva a valós környezetet. már kialakult szoftverkörnyezetbe. Érdemes még szót ejteni a felsőoktatásban használt tanulmányi rendszerről (Neptun), mely e-learning modulja (Neptun Meet Street) nem elég elterjedt, de képes a tananyagokat tárolni, megjeleníteni. A már korábban piacra került vizsgáztató rendszere (Unipoll) ismertebb, ami a kérdőív-készítéseken túl alkalmas vizsgatesztek készítésére, és az eredmények tanulmányi rendszerben történő azonnali megjelenítésére.

Mint ahogy a tananyagokat, az e-learning rendszereket is csoportosíthatjuk, elsősorban funkciókészletük alapján:

- tanulásmenedzsment-rendszer (Learning Management System - LMS): Mahnegar (2012, p. 148.) definíciója szerint ,az LMS egy olyan szoftver, amely biztosítja, nyomon követi, és menedzseli a képzést" ${ }^{\prime}$. A szakirodalom megkülönbözteti a fentit a tanulás- és tartalommenedzsment-rendszertől (Learning Content Management System LCMS), amely az e-learning tartalom (tananyag) létrehozására, szerkesztésére és strukturált tárolására alkalmas, azonban a publikálás és nyomon követés már az LMS feladata. Az egyik legismer- 
tebb LMS a jelenleg 224 országban regisztrált portállal rendelkező Moodle?.

Az LMS főbb funkciói és tulajdonságai az alábbiak:

- felhasználók kezelése, azonosítása, személyes profil kialakítása,

- kommunikációs lehetőségek: fórum, chat, wiki, üzenetküldés,

- tananyagok: szabványos és egyedi fejlesztésű tananyagok lejátszása, tanulók előrehaladásának nyomon követése,

- feladatok: egyéni állományfeltöltés, csoportmunka, mühelymunka, vizsgázás,

- felhasználóbarát felület (kevés informatikai tudást igényel, inkább csak affinitást).

- képzésmenedzsment-rendszer: az LMS-ekhez képest bővebb funkciókészlettel rendelkező informatikai megoldás, amelynek központi egységét már nem egy-egy képzés vagy kurzus jelenti, hanem leképezhető vele egy (vagy akár több) szervezet hierarchikus felépítése, kialakíthatók vele felettes-beosztott viszonyok, amelyeken keresztül az egyes tanulók képzésének szervezése egyedivé válhat. A képzésmenedzsment-rendszer alkalmas lehet továbbá kompetenciák kezelésére is, amelyeken keresztül automatizált képzésszervezés valósítható meg (gondoljunk például egy nagyvállalatra, ahol munkakörhöz, vagy szervezeti egységhez kötötten kell megadott kompetenciákkal rendelkezni, az ezek elsajátításához szükséges képzésekhez pedig a rendszer automatikusan hozzárendeli a tanulókat). A képzésmenedzsment-rendszerek hozzáadott értéke nem közvetlenül az e-learningben mutatkozik meg, sokkal inkább a képzésszervezési, adminisztrációs terheket könnyíti, illetve automatizálja. Képzésmenedzsment-rendszer például a Moodle továbbfejlesztésével létrejött Totara.

A különböző LMS-ek és képzésmenedzsment-rendszerek eltérő előnyökkel és hátrányokkal rendelkeznek (például programozási nyelv, nyílt forráskód, biztonsági megfelelőség, funkciókészlet, skálázhatóság, integrálhatóság más rendszerekkel stb.), ebből fakadóan más-más területeken használják fel őket. A Moodle például nyílt forráskódjának köszönhetően könnyedén testreszabható, így előfordulása egyetemi, vállalati és közigazgatási területeken is előfordulhat, míg az SAP LSO-ját azok a szervezetek használják előszeretettel, akiknél magát az alaprendszert (SAP) már bevezették.

\section{Eltéró célok és felhasználási közegek}

A fogalmi meghatározásokat és a terminológiai tisztázást követően érdemes elhelyezni az e-learninget nap- jainkban. Korábban már utaltam rá, hogy az e-learning egyik zászlóshajója a felsőoktatás, azonban ezen kívül ugyanúgy megtalálható a vállalati szférában is (inkább közép- és nagyvállalati szektorban), illetve a közigazgatásban. A továbbiakban arra térek ki, hogy e három szegmensben miért és hogyan alkalmazzák az e-learning megoldásokat.

\section{A felsöoktatás}

A felsőoktatásban, egyetemi közegben az e-learning leggyakrabban a kevert képzésekben jelenik meg. Ez gyakorlatilag azt jelenti, hogy a hagyományos kurzusokat az innovatív oktatók kiegészítik olyan online tanulási elemekkel, amelyek segítik a hallgatók közötti interakciókat és kommunikációt, magasabb tanulási élményt jelentenek és mélyítik a megszerzett tudást. A kiépült e-learning infrastruktúrával rendelkező egyetemeknél megvan a potenciál az adminisztrációs terhek csökkentésére is, hiszen a kurzusjelentkezések, a tanulók eredményeinek adminisztrálása is egy helyen, központilag történhet meg. Nem utolsó sorban érdemes megemlíteni az olyan jellegü kezdeményezéseket is, ahol a tanulókat bevonják a tananyag-fejlesztési projektekbe, ezáltal olyan tartalmakat elóállítva, amelyeket az egész társadalom számára nyilvánosan elérhetővé tesznek.

A felsőoktatáshoz köthetők azok a tisztán online e-learning képzések, amelyek az amerikai egyetemek (pl. Stanford, MIT, Harvard) kezdeményezéséből indultak ki, akik egyes képzéseiket teszik teljesen ingyenessé a világon bárki számára. Ezek az úgynevezett MOOC-ok (Massive Open Online Course). A képzések végén - viszont már pénzbeli ellenérték fejében - az egyetemek hivatalos igazolást is kiállítanak. A MOOC-ok kínálatában megtalálhatók minden tudomány területei, jellemzően 6-12 hétig tartanak. A tartalom alapját gyakran a videós tananyagtípus képezi, kiegészítve egyéb tartalmi elemekkel (fogalomtárak, feladatok stb.). Ezekkel a képzésekkel amellett, hogy egyfajta CSR-tevékenységet vállalnak az egyetemek, hatalmas márkanévépítő hatást is elérnek, a távolsági akadályokat legyőzve így próbálnak piacot szerezni az online lehetőségek kihasználásával.

\section{A vállalati szféra}

A profitorientált vállalati szférában is hamar megjelentek az e-learning megoldások. Ebben a közegben az elsődleges szempont a költségcsökkentés, hiszen az e-learning tananyagokon keresztül egyszeri beruházással (tananyagfejlesztés és rendszerbevezetés) kiválthatók azok a visszatérő, magas költségek, amelyek a terembérletből, a fizikai infrastruktúra fenntartásából, az oktatók fizetéséből erednek. Az effajta költségcsökkentés az alábbi környezetekben jelenthet potenciált: 
- magas fluktuációjú munkakörök: a gyárakban, gyártósorokon igen gyakori a munkaerö nagyarányú cserélődése, amely gyakori oktatási igényt generál, így e képzések e-learningesítése hatalmas terhet vehet le a vállalat válláról,

- új belépők oktatása: azok az általános érvényü képzések, amelyek az adott vállalatnál gyakorlatilag minden munkavállalót érintenek (pl. vállalati szabályzatok, standardok és módszertanok), szintén olyan szakmai anyagot képeznek, amely e-learningre átültetve csökkenthetik a költségeket, - ismétlődő képzések: akár a jogi szabályozásból fakadóan, akár belső szabályzatok nyomán szükség lehet a képzések ismétlésére (pl. munka-, tủz- és környezetvédelem, IT-biztonság stb.), amelyek gyakran az első lépést jelentik a vállalati e-learning befektetések esetében.

A fentiekben taglalt tananyagokon túl továbbá az adminisztrációs terhek csökkentése is meghatározó tényezö lehet, amikor az e-learning mellett döntenek. Itt beszélhetünk a korábban már kifejtett képzésmenedzsment-rendszerek előnyeiről, mint például az automatizált képzésszervezés, vagy éppen riportok generálása a vállalat különböző szintjein lévő munkatársak számára.

Nem pusztán anyagi oldalról megközelítve, egy következő lépés lehet az e-learningen keresztül zajló oktatások hatékonyságában rejlő potenciál kihasználása, amelyek már nemcsak költséget csökkenthetnek, hanem a vállalat versenyképességét (ezáltal természetesen bevételeit és profitját) is növelhetik. Itt gondolhatunk egyszerüen online tudásbázis kiépítésére, melyet a dolgozók maguk kezelnek és alakítanak ki (nem központi nyomás hatására), vagy a hatékony oktatási módszereken keresztül elért nagyobb teljesítőképességre, hatékonyabb munkavégzésre.

\section{A közszféra}

A közszféra és az e-learning kapcsolata valahol a felsőoktatás és a vállalati szféra között félúton helyezkedik el. Egyrészről itt is jellemzőek a költségcsökkentő kezdeményezések, hiszen a közszférában ugyanúgy megtalálható az új belépők képzése, vagy az évente kötelezően ismétlődő képzések, amelyek esetén az e-learning megoldások alkalmazása csökkentheti a szervezet anyagi vagy adminisztrációs terheit. Különösen igaz továbbá a közszférára, hogy jellemzően az adott ország számos pontján egyforma munkaköröket ellátó kollégák közötti tudásátadás, tudásmegosztás és kommunikáció egyszerüsítése valósulhat meg egy bevezetett e-learning rendszeren és tananyagokon keresztül, amely sokkal gazdaságosabb és hatékonyabb müködést tehet lehetővé.

\section{A B2C és C2C e-learning}

$\mathrm{Az}$ e-business fogalomtárából ismert $\mathrm{B} 2 \mathrm{C}$ (business-to-consumer) és $\mathrm{C} 2 \mathrm{C}$ (consumer-to-consumer) modellek (Jovarauskienè et al., 2015) az e-learningben ugyanúgy megjelennek egy olyan konstrukcióban, amely a fentiek közül talán egyik kategóriába sem sorolható. Ezek azok a képzések és kapcsolódó e-learning tartalmak, amelyeket az erre szakosodott vállalkozások állítanak össze és tesznek elérhetővé a jellemzően saját maguk által fejlesztett és kialakított e-learning felületen a végfelhasználók számára. Témájukat tekintve olyan, általában minél nagyobb potenciális célközönséget lefedő, általános és a hétköznapokban is felhasználható tudás (pl. nyelvismeret, alapvető számítógépes ismeretek) átadására irányuló képzésekről beszélhetünk, melyek árban is elérhetőek a fogyasztók számára. Az említett témákon túl továbbá fókuszált, például OKJ-s képzések megvalósítása is már gyakran elérhető e-learninges formában.

Kialakulóban van egy másik üzleti modellre épülő e-learning megoldás is, mely során magát a felületet üzemeltető vállalkozás amolyan piacteret teremt a szakértők és tudásra vágyók között. Az e-business szakirodalom ezt úgynevezett bróker modellnek nevezi (Rappa, 2004). A klasszikus bróker modellhez képest ebben az esetben a szakértők továbbá valamilyen együttmúködés keretében a felület üzemeltetőjével közösen állítják elö a szakmai tartalmat (e-learning tartalmat), és a bevételen osztozva termelnek profitot. Ezek az online kurzusok más sokkal szélesebb témákat is lefednek (a zongoraoktatástól a hatékony időmenedzsmenten át a fózésig), megvalósításuk leginkább a korábban már említett MOOC-okhoz hasonlít, jellemzően valamilyen videós tananyag keretében.

\section{Az aktuális problémák és kutatási kérdések}

Az e-learning kutatásában rengeteg potenciál rejlik, hiszen egy dinamikusan, szinte napról-napra fejlödő, viszonylag új eszköztárról beszélhetünk, amely sok megválaszolatlan kérdést vet föl. Az egyik legnagyobb nehézséget például éppen a mérhetösége adja: a konkrétan megjelenő költségeket könnyü számszerüsíteni és összevetni a korábban jelenléti oktatásokkal megvalósított képzésekkel, illetve a felhasználók (tanulók, tutorok, rendszergazdák stb.) elégedettsége - ha szubjektíven is, de - mérhető (Wang et al., 2007). Azonban a kulcskérdés, hogy valóban hatékonyabb-e az e-learning megoldások alkalmazása, már nagyon nehezen számszerüsíthető, legyen szó akár az egyénre, akár az egyénen keresztül a szervezet teljesítményére gyakorolt hatásáról. Az ez irányban található kutatások kitérnek kimondottan egyetemi adaptálhatóságra (Selim, 2007), a jelenléti, illetve az e-learning képzések ösz- 
szehasonlíthatóságára (Favretto et al., 2005), azonban olyan keretrendszer és módszertan felállítása még nem történt meg, amely egységesen és összehasonlíthatóan alkalmazható lenne az e-learning különböző előfordulási területein.

További érdekes kérdést vet föl, hogy milyen módszerek a legalkalmasabbak az e-learning bevezetések során: vajon informatikai projektnek minősül-e egy e-learning bevezetés, vagy más oldalról kell megközelíteni azt? Bár több évtizede léteznek különféle képzésfejlesztésre irányuló modellek, mint az ADDIE vagy a SAM-modell, melyek egy meglévő vagy új képzés kialakításához adnak támpontokat: hogyan elemezzük a célközönséget, hogyan döntsük el, hogy érdemes-e az e-learning eszköztárát is alkalmazni, hogy mérjük a tanulók eredményeit stb. E modellek alkalmazása azonban meglehetősen nehéz a túlságosan egyedi képzések és szervezeti igények miatt. A témában Molenda (2003) és Kearsley (2000) kutatásai rendkívül jó alapot jelentenek.

A fentiekhez képest egyet hátra lépve, magának az e-learningnek a pedagógiája is megkérdőjelezhető: az ezzel kapcsolatos kritikák azt taglalják, hogy vajon a kvázi magára hagyott tanulók képesek-e önállóan kitaposni a tanulás ösvényét, vagy ezzel a megközelítéssel halálra van ítélve ez az új oktatási forma. Ezen a területen érdemes lehet a tanulói motivációról, a virtuális coach-okról és tutorokról kutatásokat keresni, vagy McGonigal (2011) játékosítás (gamification) témájú könyve is érdekes következtetéseket von le.

\section{Záró gondolatok}

\section{Az e-learning pillérjei}

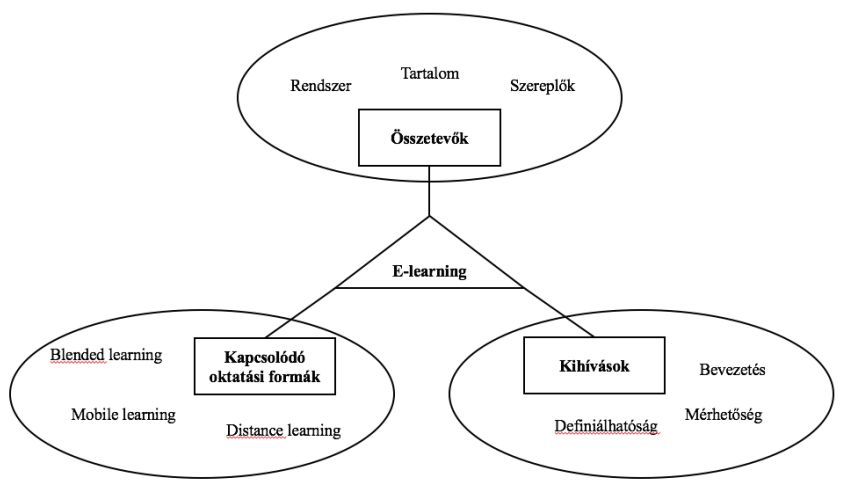

Forrás: saját szerkesztés

Összességében tehát kijelenthető, hogy az e-learning egy olyan terület, amely egyrészt megosztja mind a lai- kus, mind az akadémiai köröket, azonban épp ez a sokszínűség teszi érdekes kutatási területté, annak minden ágával és kapcsolódásával együtt. Cikkem elején azt a célt tủztem ki magam elé, hogy tisztázzam az e-learning alapvetö fogalmait, pillérjeit (3. ábra), és meghatározzam azt a közeget és motiváló erőket amelyek a mai formájában vett e-learning leggyakoribb felhasználási területeit jelentik és alakítják. A fenti irodalmi áttekintésen túl célszerünek tartok egy olyan empirikus kutatást elvégezni (akár csak magyarországi viszonylatban), amely az e-learningről és a kapcsolódó témákról kialakított képet vizsgálja a hazai tudományos és mindennapi közegben, összehasonlítva azt a nemzetközi irodalomban található hasonló empirikus kutatásokkal.

\section{Lábjegyzet}

„E-learning is to take a course online using a modem, wireless, or cable connection to access academic course material from a computer, phone, or handheld device."

„E-learning can be loosely defined as a wide set of applications and processes, which uses available electronic media (and tools) to deliver vocational education and training."

3 ,(E-learning is) an innovative approach for delivering well-designed, learner-centered, interactive, and facilitated learning environment to anyone, anyplace, anytime (...)".

${ }^{4}$, ,E-learning is) the appropriate application of the Internet to support the delivery of learning, skills and knowledge in a holistic approach not limited to any particular courses, technologies, or infrastructures."

„(Blended learning is) the thoughtful integration of online and face-to-face instruction."

„A Learning management system (LMS) is software used for delivering, tracking and managing training/education."

7 2016. január 3-i adat. Az aktuális statisztika megtekinthető a https://moodle.net/stats/?lang=hu linken.

\section{Felhasznált irodalom}

Abbas, Z. - Umer, M. - Odeh, M. - McClatchey, R. - Ali, A. - Farooq, A. (2005, May): A semantic grid-based e-learning framework (SELF). in: Cluster Computing and the Grid, 2005. CCGrid 2005. IEEE International Symposium, vol. 1, p. 11-18.

Allen, V. L. (ed.). (2013): Children as teachers: Theory and research on tutoring. New York: Academic Press

Clark, T. A. (1989): Distance education: its effectiveness and potential use in lifelong learning. Journal of Lifelong Learning, v12 n4, p. 24-27.

Drysdale, J. S. - Graham, C. R. - Spring, K. J. Halverson, L. R. (2013): An Analysis of Research Trends in Dissertations and Theses Studying Blended Learning. Internet and Higher Education, 17, p. $90-100$.

Favretto, G. - Caramia, G. - Guardini, M. (2005): E-learning measurement of the learning differences between traditional lessons and online lessons. 
European Journal of Open, Distance and e-Learning, 8 (2), p. 1-8.

Field, J. (2000): Lifelong learning and the new educational order. London: Trentham Books

Governors State University, Center for Online Learning and Teaching (2008): E-learning glossary, www.govst.edu/elearning/default.aspx

Guri-Rosenblit, S. - Gros, B. (2011): E-learning: Confusing terminology, research gaps and inherent challenges. International Journal of E-Learning \& Distance Education, 25(1)

Henry, P. (2001): E-learning technology, content and services. Education+ Training, 43(4/5), p. 249-255.

Herrington, J. - Oliver, R. (2000): An instructional design framework for authentic learning environments. Educational technology research and development, 48(3), p. 23-48.

Jovarauskienè, D. - Pilinkiené, V. (2015): E-Business or E-technology? Engineering Economics, 61(1)

Kearsley, G. (2000): Online education: Learning and teaching in cyberspace (Vol. 91). Belmont, CA: Wadsworth

Khan, B. (2005): Learning features in an open, flexible and distributed environment. AACE Journal, 13(2), p. $137-153$

King, F. B. - Young, M. F. - Drivere-Richmond, K. Schrader, P. G. (2001): Defining distance learning and distance education. AACE Journal, 9(1), p. 1-14.

Krishnamurthy, A. - O'Connor, R. V. (2013): An analysis of the software development processes of open source E-learning systems. in: Systems, Software and Services Process Improvement. Berlin; Heidelberg: Springer, p. 60-71.

Mahnegar, F. (2012): Learning management system. International Journal of Business and Social Science, 3(12), p. 144-150.

Martin, F. - Ertzberger, J. (2013): Here and now mobile learning: An experimental study on the use of mobile technology. Computers \& Education, 68, p. 76-85.

McGonigal, J. (2011): Reality is broken: Why games make us better and how they can change the world. London: Penguin
Mittal, A. - Krishnan, P. V. - Altman, E. (2006): Content classification and context-based retrieval system for e-learning. Journal of Educational Technology \& Society, 9(1), p. 349-358.

Molenda, M. (2003): In search of the elusive ADDIE model. Performance Improvement, 42(5), p. 34-37.

Moore, J. L. - Dickson-Deane, C. - Galyen, K. (2011): e-Learning, online learning, and distance learning environments: Are they the same? The Internet and Higher Education, 14(2), p. 129-135.

Parmar, A. (2012, January): Paper Review on Sharable Content Object Reference Model (SCORM): Framework for E-learning Standard. in: Advanced Computing \& Communication Technologies (ACCT), 2012 Second International Conference, p. 409-411.

Poltrack, J. - Hruska, N. - Johnson, A. - Haag, J. (2012): The next generation of scorm: Innovation for the global force. in: The Interservice/Industry Training, Simulation \& Education Conference (I/ ITSEC) (Vol. 2012, No. 1)

Rappa, M. A. (2004): The utility business model and the future of computing services. IBM Systems Journal, 43(1)

Robinson, K. (2006): Do schools kill creativity? TED2006, https://www.ted.com/talks/ken_robinson says schools kill creativity

Robinson, K. (2010): Bring on the learning revolution. TED2010, https://www.ted.com/talks/sir_ken_robinson_bring_on_the revolution

Sangrà, A. - Vlachopoulos, D. - Cabrera, N. (2012): Building an inclusive definition of e-learning: An approach to the conceptual framework. The International Review of Research in Open and Distributed Learning, 13(2), p. 145-159.

Selim, H. M. (2007): Critical success factors for e-learning acceptance: Confirmatory factor models. Computers \& Education, 49(2), p. 396-413.

Wang, Y. S. - Wang, H. Y. - Shee, D. Y. (2007): Measuring e-learning systems success in an organizational context: Scale development and validation. Computers in Human Behavior, 23(4), p. 1792-1808. 